\title{
Differential effects of all-trans-retinoic acid (RA) on Erk1/2 phosphorylation and cAMP accumulation in normal and malignant human prostate epithelial cells: Erk1/2 inhibition restores RA-induced decrease of cell growth in malignant prostate cells
}

\author{
Daniela Pasquali, Paolo Chieffi ${ }^{1}$, William J Deery ${ }^{3}$, Gianfranco Nicoletti ${ }^{2}$, Antonio Bellastella and Antonio A Sinisi \\ Endocrinologia, Dipartimento Medico-Chirurgico di Internistica Clinica e Sperimentale F Magrassi e A Lanzara, Centro di Ricerca sulle Malattie \\ Cardiovascolari, ${ }^{1}$ Dipartimento di Medicina Sperimentale and ${ }^{2}$ Plastic and Reconstructive Surgery, Seconda Università di Napoli, Naples, Italy and \\ ${ }^{3}$ Department of Biochemistry and Cell Biology, Rice University, Houston, Texas, USA
}

(Correspondence should be addressed to A A Sinisi, Istituto di Endocrinologia, Seconda Università di Napoli, Building 16, Via Pansini 5, 80131 Naples, Italy; Email: antonio.sinisi@unina2.it)

\begin{abstract}
Objective: All-trans-retinoic acid (RA) regulates cellular growth, differentiation and apoptosis in human prostate by binding to RA receptors. Non-genomic retinoid effects on signal transduction kinases in the cytoplasm are also described in several cells but they are still unknown in prostate cells. Methods: Using an epithelial cell line derived from normal human prostate (EPN), and normal (NPEC) and malignant (CPEC) epithelial primary cultures of human prostate, we have examined effects of RA on both extracellular signal-regulated kinase 1/2 (Erk1/2) and cAMP accumulation. Then we have verified the effect of the inhibition of Erk1/2 on RA-induced growth arrest and apoptosis in malignant cells.

Results: In NPEC and in EPN treated with RA for up to $24 \mathrm{~h}$, Western blot analyses of Erk1/2 phosphorylation show that RA causes a rapid activation of Erk $1 / 2$ within $5 \mathrm{~min}$, which is maintained for $30 \mathrm{~min}$, followed by a return to basal levels. In CPEC, the activated phosphorylation levels persist up to $24 \mathrm{~h}$. While basal cAMP levels are not affected by 30 min treatment with RA in both EPN and NPEC, levels are increased in CPEC. Forskolin-induced cAMP levels are decreased by RA in all cell types. CPEC were incubated for up to $96 \mathrm{~h}$ with RA with and without the inhibitor of Erk $1 / 2$, UO126. CPEC incubated with RA and UO126 for $72 \mathrm{~h}$ showed a significant arrest of cell growth and after $96 \mathrm{~h}$ apoptosis in $11 \%$ of cells.

Conclusions: We show rapid effects of RA on cytoplasmic messenger pathways in human prostate, and that responses can differ between normal and malignant cells. The inhibition of these pathways could improve the efficiency of RA in prostate cancer growth control.
\end{abstract}

European Journal of Endocrinology 152 663-669

\section{Introduction}

Prostate cancer is the sixth most common in the world (in the number of new cases), and for men, the third overall and most common in Europe, North America and some parts of Africa (1). The growth of prostate cancer at the beginning is usually androgen-dependent, but often after androgen-deprivation therapy, it becomes androgen-independent and progresses in most cases (2). Thus, managing hormone-refractory prostate carcinoma is a difficult clinical challenge, and the actual tools to treat such relapses remain limited. Retinoids, vitamin A and related synthetic analogs are some of the most studied chemopreventive drugs for prostate cancer $(3,4)$. Retinoids play a key role in vital functions such as vision, and also affect tissue development and cellular proliferation (5). The effects of alltrans-retinoic acid (RA), a natural active derivative of vitamin $A$, and its synthetic derivatives on both the prostate gland and prostate cell lines implicate retinoids in both regulating prostate growth and in suppressing the development of prostate carcinogenesis (6-11). Anti-proliferative effects of retinoids appear to operate on intracellular pathways involved in regulating cell differentiation, proliferation and apoptosis (5, 12). Effects of retinoids are mediated by two classes of nuclear proteins called retinoic acid and retinoic $\mathrm{X} \alpha$, $\beta$ and $\gamma$ receptors (RAR and RXR respectively), which are ligand-regulated transcription factors (13). While the genomic effects are characterized by delayed onset 
of action and sensitivity to blockers of transcription and protein synthesis, only recently have rapid actions of steroids and members of the nuclear hormone superfamily been more widely recognized and characterized in detail. Although retinoids have appeared to exert their anti-tumor effects through the activation of RAR and RXR, recent reports suggested that these compounds also have significant effects on cytoplasmic signaling kinases, such as protein kinase $\mathrm{C}$ and mitogen-activated protein kinase (MAPK) (14-19). Tissues traditionally considered as 'non-targets' for classic steroid actions are indeed extensively regulated by non-genomic pathways. Target cells and organs are regulated by a complex interplay of the genomic and non-genomic signaling mechanisms of nuclear hormones, and the integrated actions of these processes have significant functional roles in several pathophysiological disorders (20). Understanding the molecular basis of rapid hormonal effects may in the future be relevant for clinical purposes. In human prostate cells, for example, non-genomic effects of RA are still unknown.

Here we investigated the hypothesis that RA may act through non-genomic pathways in prostate cells. We studied the effects of RA on extracellular signal-regulated kinase 1/2 (Erk1/2) activation, and intracellular cAMP accumulation using as models the novel normal prostate epithelial cell line EPN (21), and primary cultures of normal and malignant human prostate cells. Moreover we tested the effect of UO126, an inhibitor of MEK1/2 (the upstream activator of the Erk), on RA cell growth and apoptosis control in primary cultures of epithelial prostate cancer cells.

\section{Materials and methods}

\section{Primary cultures, EPN and reagents}

Normal human prostatic tissues were collected from patients (aged 60-81 years) who had undergone radical cystectomy for bladder cancer. Prostate cancer tissues were obtained from patients (aged 56-79 years) who had undergone radical prostatectomy (Gleason score 6-8). After prostatectomy, a wedge-shaped specimen of the fresh prostate was removed. A sample of the tissue underwent pathological examination to confirm the prostatic origin, the diagnosis and the absence of other diseases. Only specimens containing 100\% cancerous prostate cells were used to establish primary cultures according to a previously described method (10). Normal prostate epithelial cells (NPEC) and malignant prostate epithelial cells (CPEC) were separated by different centrifugations of minced and collagenase $(10 \mathrm{mg} / \mathrm{ml})$-digested tissues (Collagenase IV; GibcoBRL). The ECs were plated on keratinocyte-SFM medium (Gibco-BRL) supplemented with bovine pituitary extract $(10 \mathrm{mg} / \mathrm{ml})$, epidermal growth factor $(10 \mathrm{ng} / \mathrm{ml})$, cholera toxin $(10 \mathrm{ng} / \mathrm{ml}), 5 \%$ fetal calf serum (FCS) and antibiotics (Fungizone and penicillin-streptomycin). At confluence, cultures were then split and grown after EDTA-trypsin treatment. Four cell strains from normal prostates and four from prostate cancer specimens were used in the experimental protocols, which were repeated at least three times. EPN were cultured in HAM-F12 supplemented with 3\% FCS and antibiotics (Fungizone and penicillin-streptomycin) (21). All cultures were maintained at $37^{\circ} \mathrm{C}$ in a humidified $5 \% \mathrm{CO}_{2}$ atmosphere.

RA solution was dissolved in ethanol, the final ethanol concentration in the experimental medium per plate was $0.001 \%$. The same amount of solvent was added to the control cells during the experimental protocol. The solvent had no effect on cells morphology. Stock solution of $20 \mathrm{mmol} / \mathrm{l} \mathrm{UO126}$ (Promega), an inhibitor of MEK1/2, was prepared in DMSO and stored as per manufacturer's instruction.

\section{Cell stimulation and Western blot analysis}

EPN, NPEC and CPEC cells were serum starved for $24 \mathrm{~h}$ then treated with RA (Sigma) at $10^{-7} \mathrm{~mol} / \mathrm{l}$. At the end of the incubation, cells were washed three times with

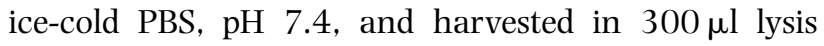
buffer $(50 \mathrm{mmol} / \mathrm{l} \mathrm{Hepes,} 150 \mathrm{mmol} / \mathrm{l} \mathrm{NaCl}, 1 \mathrm{mmol} / \mathrm{l}$ EDTA, $1 \mathrm{mmol} / \mathrm{l}$ EGTA, 10\% glycerol, 1\% Triton $\mathrm{X}-100,1 \mathrm{mmol} / \mathrm{l}$ phenylmethylsulfonyl fluoride, $1 \mu \mathrm{g}$ aprotinin, $\quad 0.5 \mathrm{mmol} / \mathrm{l}$ sodium orthovanadate, $20 \mathrm{mmol} / \mathrm{l}$ sodium pyrophosphate). The lysates were incubated $30 \mathrm{~min}$ on ice, and then clarified by centrifugation at $14000 \mathrm{~g}$ for $10 \mathrm{~min}$. Total protein concentration was estimated by a modified Bradford assay (Bio-Rad). For Western blots, $25 \mu \mathrm{g}$ /lane of total proteins were separated on $0.1 \%$ SDS $/ 10 \%$ polyacrylamide gels. Proteins were then transferred to PVDF membranes (Immobilon-P; Millipore Corporation, Bedford, MA, USA); complete transfer was assessed using prestained protein standards (Bio-Rad). The membranes were blocked in $25 \mathrm{mmol} / \mathrm{l}$ Tris, $\mathrm{pH} \mathrm{7.4,} 200 \mathrm{mmol} / \mathrm{l}$ $\mathrm{NaCl}, 0.5 \%$ Triton $\mathrm{X}-100$ and 5\% non-fat powdered milk for $2 \mathrm{~h}$ at room temperature. Incubations with the primary antibody (anti-Erk1/2 at 1:2000, antiphospho-Erk $1 / 2$ at 1:2000) were carried out at room temperature for $1 \mathrm{~h}$. Finally, the membranes were incubated with the horseradish peroxidase-conjugated secondary antibody (1:2000) for $45 \mathrm{~min}$ at room temperature, and the reactions were detected with an ECL system (Amersham).

\section{Antibodies}

Antibodies were purchased from the following sources: polyclonal anti-phospho-p44/42 MAPK (Thr202/Tyr204) antibody (\#9101S; New England Biolabs, Beverly, MA, USA); polyclonal anti-Erk1 antibody (\#sc-94-G; Santa Cruz Biotechnology, Inc., Santa Cruz, CA, USA). 


\section{cAMP production}

Confluent EPN, NPEC and CPEC monolayers in six-well plates (Costar, Milan, taly) were starved for $24 \mathrm{~h}$ in medium without FCS, then moved to medium supplemented with 1\% FCS and phosphodiesterase inhibitor. The cells were treated with forskolin $\left(10^{-5} \mathrm{~mol} / \mathrm{l}\right)$, 3-methyl-1-isobutylxanthine $(0.5 \mathrm{mmol} / \mathrm{l})$ and RA $\left(10^{-7} \mathrm{~mol} / \mathrm{l}\right)$ alone or with forskolin. After $30 \mathrm{~min}$, cultures were interrupted by adding cold $70 \%$ ethanol. After overnight incubation in ethanol, the supernatant was collected, centrifuged and dried. The extracts were reconstituted with the appropriate buffer and processed for cAMP assay using an RIA kit (Amersham).

\section{Cell proliferation assay}

Cell proliferation was evaluated with the tetrazolium salts (MTT) method (Roche). As previously described (11) the Cell Proliferation kit is a colorimetric assay (MTT based) for the non-radioactive quantification of cell proliferation and viability. Only metabolically active cells cleave MTT to form a formazan dye detected by UV (the absorbance spectrum is between 550 and $600 \mathrm{~nm}$ ). Cells were seeded in microtiter plates in a final volume of $100 \mu \mathrm{l}$ complete culture medium at a concentration of $2 \times 10^{3}$ cells/well and grown for $24 \mathrm{~h}$ at $37^{\circ} \mathrm{C}$ in $5 \% \mathrm{CO}_{2}$. Cells, starved for $24 \mathrm{~h}$ in MEM without FCS, were incubated in 1\% FCS-supplemented medium in the presence of RA at $10^{-8}$, $10^{-7}$ and $10^{-6} \mathrm{~mol} / \mathrm{l}$, with and without U0126 $\left(10^{-5} \mathrm{~mol} / \mathrm{l}\right)$ or solvent (control cells) for up to $96 \mathrm{~h}$. Then $10 \mu \mathrm{l}$ of the MTT solution were added to each well and plates were further incubated for $4 \mathrm{~h}$. Ten microliters of solubilization solution were added to each well and plates were kept overnight in the incubator according to the manufacturer's protocol. The absorbency was read at $550 \mathrm{~nm}$ using a microtiter plate reader.

\section{Apoptosis detection}

The In Situ Cell Death Detection Kit (Roche) (TUNEL), was used to detect apoptosis and quantify DNA strand breaks in individual cells. The cell monolayers were grown directly on sterilized slides (Superfrost; Carlo Erba, Milan, Italy), starved for $24 \mathrm{~h}$ in MEM without FCS, then incubated in $1 \%$ FCS-supplemented medium in the presence of RA $\left(10^{-7} \mathrm{~mol} / \mathrm{l}\right)$, with and without UO126 $\left(10^{-5} \mathrm{~mol} / \mathrm{l}\right)$ or solvent (control cells) up to $96 \mathrm{~h}$. The slides were then fixed in buffered paraformaldehyde, permeabilized with Triton-X and labeled with TUNEL reaction mixture according manufacturer's instructions. Samples were analyzed using a Leitz Diaplan microscope equipped with epifluorescence. A negative control (obtained by incubating a slide with labeled solution without terminal transferase) and a positive control (obtained by treating a slide with DNAase I solution) were included in each assay run. Apoptosis of cultured cells was analyzed by two investigators in a blinded fashion without knowledge of the experimental group. All stained nuclei were scored as positive for apoptosis. The TUNEL-positive rate was determined by observing more than 1000 nuclei for each experimental sample.

\section{Statistical analysis}

The data are reported as means \pm S.E. obtained from at least three separate experiments in which each point was performed in triplicate. The means were compared using ANOVA.

\section{Results}

\section{RA activation of Erk1/2 pathway differs between normal and malignant prostate epithelial cells}

In order to determine if RA activated the Erk $1 / 2$ pathway in EPN and in normal (NPEC) and malignant (CPEC) human prostate cells, cultures starved for $48 \mathrm{~h}$ and maintained in $0.5 \%$ FCS were treated with $10^{-7} \mathrm{~mol} / \mathrm{l} \mathrm{RA}$. Erk1/2 activation was then determined by Western blot analyses of cell lysates prepared after 5 , 15,30 and $60 \mathrm{~min}$, and 6,12 and $24 \mathrm{~h}$ of treatment. Figure $1 \mathrm{~A}$ and $\mathrm{B}$ show that within $5 \mathrm{~min}$, RA caused a rapid phosphorylation of Erk $1 / 2$, which was sustained up to $30 \mathrm{~min}$, and then decreased to near basal levels for the duration of the experiment in EPN and NPEC cultures. In CPEC cultures, RA also induced a significant phosphorylation of Erk1/2 after $5 \mathrm{~min}$, but in contrast to normal cells, the increased phosphorylation levels persisted up to $24 \mathrm{~h}$ (Fig. 1C). The reactivity on blots with the anti-Erk1/2 and anti-phosphoThr/Tyr demonstrated that the effect of RA on Erk1/2 was due to phosphorylation of the enzyme and not an increase of Erk $1 / 2$ expression, since no change in Erk1/2 protein was observed (Fig. $1 \mathrm{~A}-\mathrm{C}$, lower panels).

\section{$R A$ affects cAMP accumulation in normal and malignant prostate epithelial cells}

Constant elevated levels of intracellular cAMP can cause either proliferation, differentiation or cell death depending on the stage of the cell cycle (22). Furthermore, in prostate tumor $\mathrm{LNCaP}$ cells, a transient increase in cAMP induced by pituitary adenylate cyclase activation peptide stimulates cell proliferation, whereas chronically sustained increases inhibit proliferation and induce differentiation (23). We were therefore interested in knowing what effect RA has on cAMP levels in our cell systems. As shown in Fig. 2, a 30 min incubation in forskolin, which directly activates the catalytic subunit of adenylate cyclase, increased cAMP levels by 74,64 and $84 \%$ over basal in EPN, NPEC and CPEC cells respectively. Addition of 


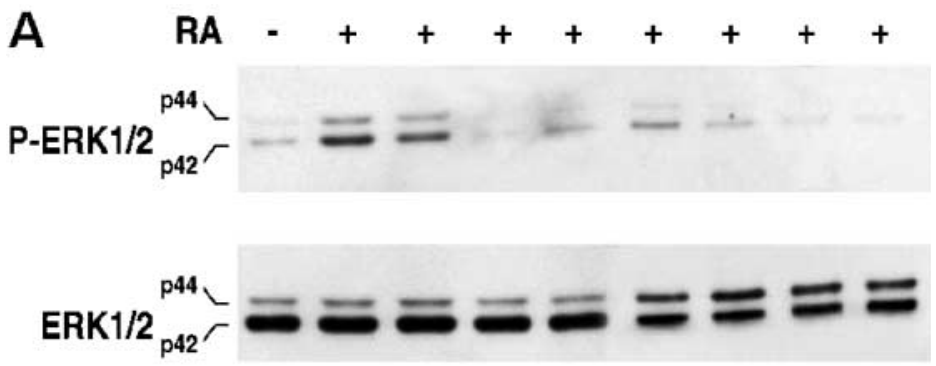

B
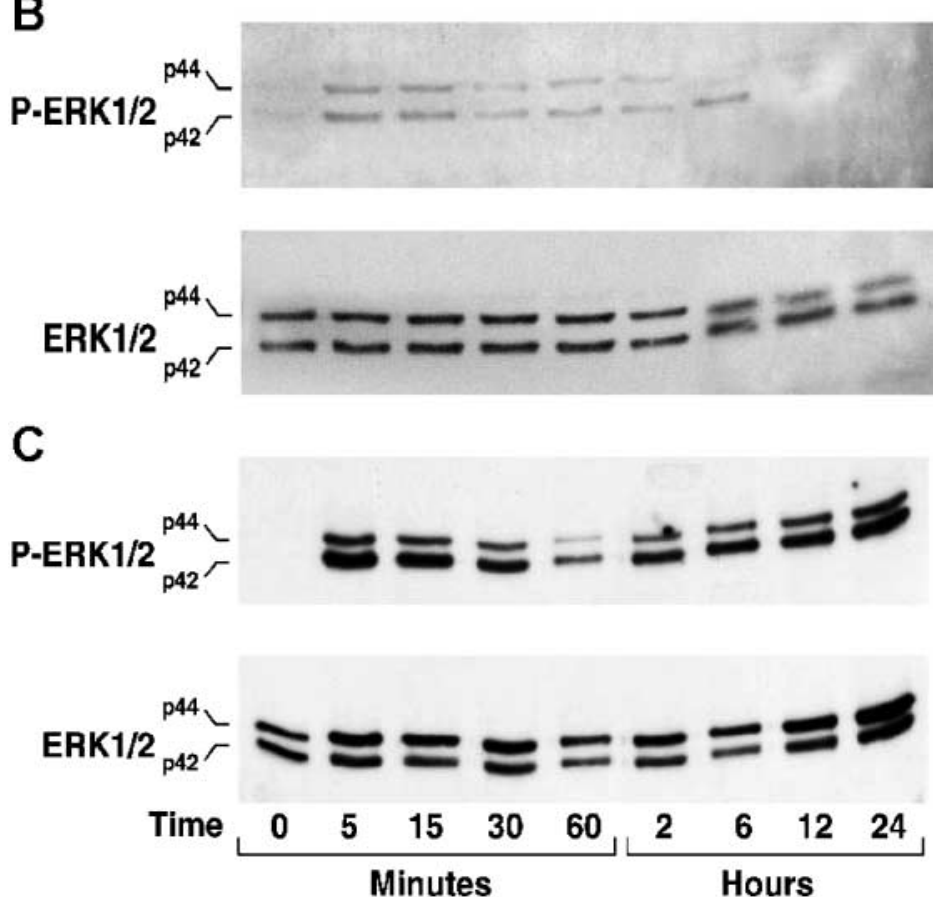

Figure $1 \mathrm{RA}$ induces rapid activation of Erk1/2 in EPN cells, in normal (NPEC) epithelial prostate cells and a rapid and sustained activation in malignant (CPEC) prostate epithelial cells. EPN (A), NPEC (B) and CPEC $(C)$ were treated for the indicated times with $10^{-7} \mathrm{~mol} / \mathrm{l}$ RA. Cells were lysed, and aliquots of the whole cell extract were used for the Western blot detection of Erk1/2 proteins as described in Materials and methods. The upper panels of $(A),(B)$ and $(C)$ show blots incubated with antibody raised against phospho-Erk1/2, and the lower panels of $(A),(B)$ and (C) show blots with antibodies against Erk1/2 protein. Two specific bands are observed at 44 and $42 \mathrm{kDa}$. The blots are representative of three separate experiments.
RA resulted in a 76, 70 and 33\% decrease in these respective forskolin-stimulated levels. Interestingly, while incubation with RA did not significantly affect basal cAMP in the EPN and NPEC cells, a 43\% increase in the basal level was observed in the CPEC cells.

\section{CPEC treated with $R A$ and UO126 show growth arrest, and different degrees of apoptosis}

RA induces growth arrest and apoptosis in NPEC only (10). To verify the effect of the inhibition of Erk $1 / 2$ on RA-induced growth arrest, CPEC were incubated for up to $96 \mathrm{~h}$ with RA at $10^{-8}, 10^{-7}$ and $10^{-6} \mathrm{~mol} / \mathrm{l}$ with and without UO126 at $10^{-5} \mathrm{~mol} / \mathrm{l}$, the concentration described previously (24). CPEC treated with RA at $10^{-7}$ and $10^{-6} \mathrm{~mol} / \mathrm{l}$ alone, for 48,72 and $96 \mathrm{~h}$ did not show a significant decrease of cell growth as previously shown (10). In the presence of Erk inhibition via U0126 at $10^{-5} \mathrm{~mol} / \mathrm{l}$ alone, the numbers of live cells were significantly $(P<0.05$ vs RA and untreated controls) decreased after $72 \mathrm{~h}$. The cell growth inhibition was greater $(P<0.01$ vs RA and untreated controls) when cells were incubated with RA at $10^{-7} \mathrm{~mol} / \mathrm{l}$ and UO126 at $10^{-5} \mathrm{~mol} / \mathrm{l}$ (Fig. 3). The arrest of cell growth was present for up to $96 \mathrm{~h}$ of drug exposure (Fig. 3). RA at lower doses $\left(10^{-8} \mathrm{~mol} / \mathrm{l}\right)$ in the presence of UO126 at $10^{-5} \mathrm{~mol} / \mathrm{l}$ did not reduce significantly cell growth (data not shown). At $96 \mathrm{~h}$ of drug exposure nuclear fragmentation indicating programmed cell death by TUNEL was detected in $7 \%$ of UO126 at $10^{-5} \mathrm{~mol} / \mathrm{l}$ alone- and in $11 \%$ of RA at $10^{-7} \mathrm{~mol} / \mathrm{l}$ - and UO126 $10^{-5} \mathrm{~mol} / \mathrm{l}$-treated cells (Fig. 4).

\section{Discussion}

The availability of natural retinoid (i.e. RA) plays a key role in normal cellular differentiation, and also exerts anti-proliferative effects on both normal and cancerous human prostate cells (9). At the genomic level, inhibition of growth by RA involves specific RAR subtypes $\operatorname{RAR} \alpha$ and $\beta$, which can mediate retinoid action in 
A

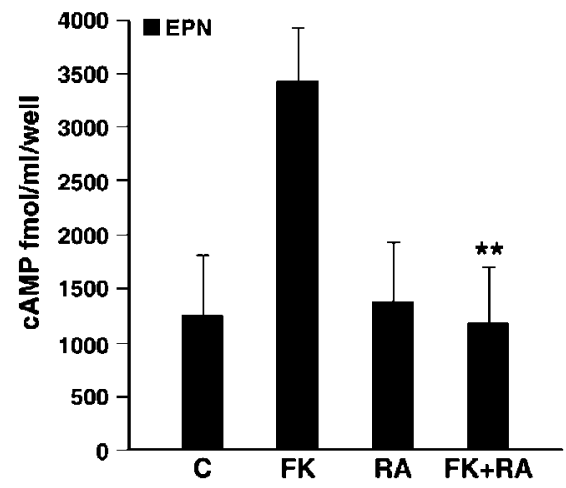

B

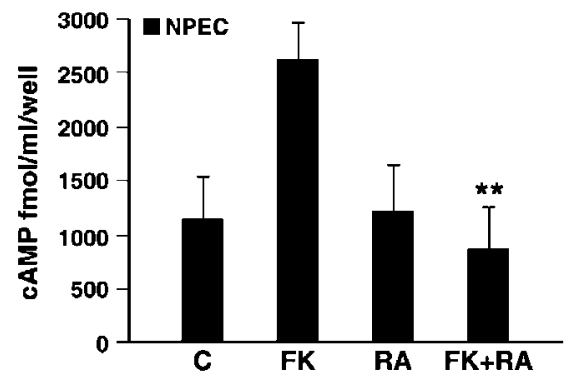

C

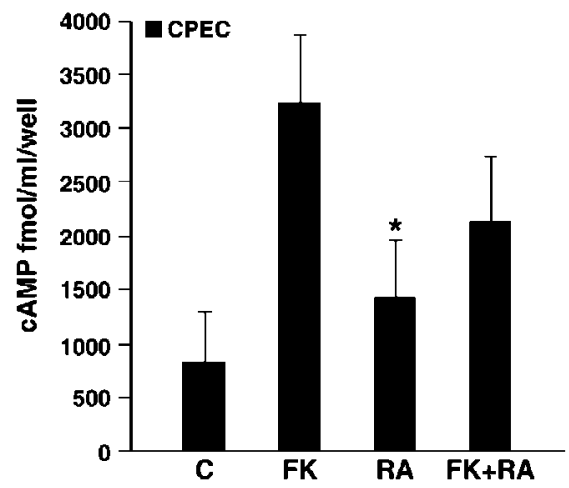

Figure 2 RA induces inhibition of forskolin (FK)-stimulated cAMP accumulation in cell cultures from EPN and normal (NPEC) and increases basal cAMP levels in malignant (CPEC) prostate epithelial cells. The cells were either not treated (basal) or treated with $\mathrm{FK}$ at $10 \mu \mathrm{mol} / \mathrm{l}$ and 3-methyl-1-isobutylxanthine $(0.5 \mathrm{mmol} / \mathrm{l})$ for $30 \mathrm{~min}$ with or without RA at $10^{-7} \mathrm{~mol} / \mathrm{l}$ for $30 \mathrm{~min}$, and then processed for the assay of cAMP content with an RIA kit as described in Materials and methods. Each column represents the mean \pm S.E. of three separate experiments $\left({ }^{\star} P<0.05\right.$ vs control; ${ }^{*} P<0.001$ vs FK-stimulated cAMP accumulation).

primary prostate cell culture by down-regulating RAR $\alpha$ and $\beta$ mRNA in NPEC but increasing RAR $\beta$ in CPEC (10). Phosphorylation of RARs at conserved serine residues in N-terminal domains is increased in response to RA subsequent to p38 MAPK (p38MAPK) activation. Interestingly, activation of p38MAPK has been associated with a cascade of phosphorylation reactions involving upstream kinases as Erk1/2 (25-29), and the altered phosphorylation of RARs results in aberrant transcriptional activity and proteasomal degradation. While other studies have also demonstrated that retinoids control aberrant prostate cell growth in vitro, and inhibit the development of prostate malignancy (11), the anti-proliferative or apoptotic effects are unfortunately limited in prostate cancer. This could in part be related to our present findings that rapid, non-genomic actions of RA on both Erk1/2 activation and cAMP levels in human epithelial prostate cells differ between normal and malignant cells. Inhibiting these effects by specific Erk pathway inhibitors may improve the efficiency of RA in prostate cancer growth control, as suggested by our present finding. RA has been found to activate Erk1/2 pathways in various cellular models (30-33). In both EPN and NPEC, we find that the Erk1/2 pathway is activated by RA treatment within $5 \mathrm{~min}$, and then is reduced close to basal activity after $30 \mathrm{~min}$. The rapid stimulation of the pathway is similar to many extracellular signals which activate cytoplasmic signal transduction pathways, and it is possible that RA directly interacts either with an enzyme(s) in the phosphorylation pathway that could affect RARs-RXRs mediated actions or indirectly through a putative cytoplasmic receptor protein. In CPEC, although the RA-induced Erk1/2 activation also starts within $5 \mathrm{~min}$, it is sustained for up to $24 \mathrm{~h}$. Thus, the difference in duration of Erk $1 / 2$ phosphorylation levels suggests that regulatory kinases and/or phosphatases upstream and/or downstream of Erk1/2 are altered in tumor cells. Indeed, a number of cancer processes have been linked with constitutively high Erk1/2 activity (34), which could in turn result in the altered activities of downstream kinases and other target proteins, and contribute to the transformed cell phenotype affecting the cell growth control. We found that by inhibiting this mechanism(s), and attenuating Erk1/2 phosphorylation levels the efficiency of RA treatment could be improved. One of the crucial factors that can determine the outcome of $\mathrm{LNCaP}$ prostatic cancer cell progression is the difference between transient vs sustained intracellular cAMP increases by the neuropeptide pituitary adenylate cyclase-activating polypeptide (23). Cell proliferation was found associated with cAMP stimulation of protein kinase A, and subsequent activation of the MAPK cascade. We find that in addition to the Erk1/2 pathway, RA can affect cAMP accumulation in EPN, NPEC and CPEC cultures, with differences between normal and malignant cells. While RA does not affect basal cAMP levels in EPN and NPEC, it significantly reduces forskolin-stimulated cAMP accumulation in all cell types. Since forskolin directly stimulates adenylyl cyclase catalytic subunit activity, and RA reduces this activity in all the cell types without inhibiting basal levels, it is possible that RA interferes with the forskolin-catalytic subunit interaction. However, most significantly, RA treatment increases basal cAMP in CPEC cells to levels that are approximately $50 \%$ less than that induced by forskolin. Such elevated cAMP levels could be detrimental in malignant cells since, for example, Farini et al. (23) 


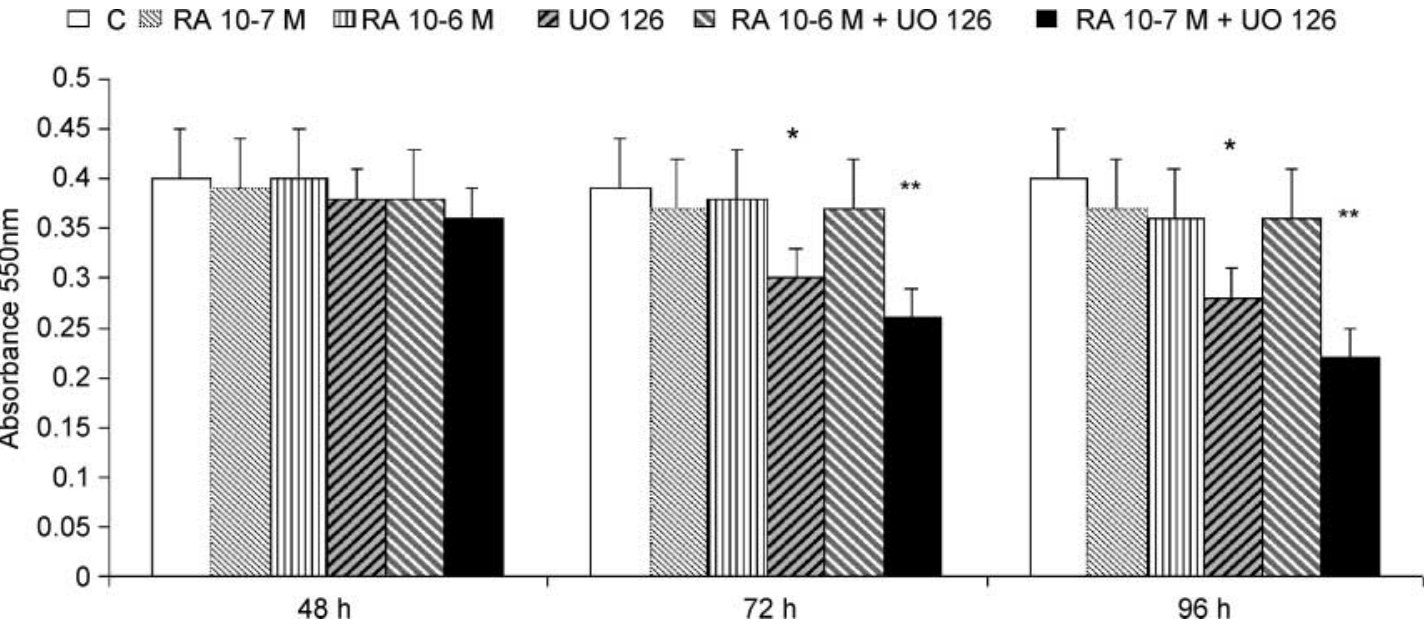

Figure 3 Effect of UO126 on RA-induced growth inhibition in CPEC. The cells were seeded at 2000 cells per well and treated with RA at $10^{-7}$ or $10^{-6} \mathrm{~mol} / /$, for 48,72 and $96 \mathrm{~h}$ with and without $U 0126$ at $10^{-5} \mathrm{~mol} / /$. The results were expressed as the $A_{550}$ of MTT-derived formazan developed by untreated control $(C)$ and treated cells. Each column represents the mean $\pm S$.E. of three separate experiments $\left({ }^{\star} P<0.05 ;{ }^{\star *} P<0.01\right)$.

found that sustained cAMP accumulation leads to proliferation arrest and neuroendocrine differentiation.

In conclusion, our results demonstrate a rapid, nongenomic effect of RA on cytoplasmic signaling pathways in EPN, NPEC and CPEC, with a different response between normal and malignant prostate cells. In the presence of Erk inhibition via UO126 $\left(10^{-7} \mathrm{~mol} / \mathrm{l}\right)$, RA caused a significant decrease of the numbers of live cells and induced apoptosis in CPEC. These observations could suggest that the combination of retinoids with agents that affect pathways such as Erk1/2 and cAMP accumulation could be exploited both in vitro and at the clinical level to improve retinoid treatment and/or reverse RA resistance. A similar strategy to enhance proapoptotic potential of neuroendocrine-differentiated malignant prostate cells has recently been proposed which would target abnormal intracellular calcium homeostasis (35).

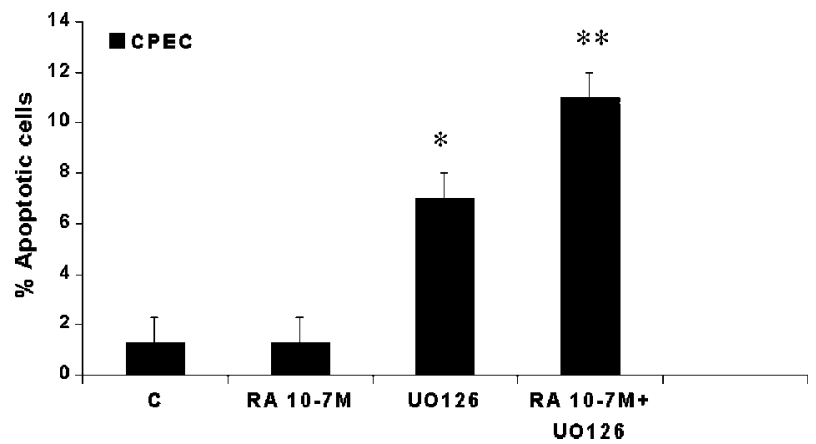

Figure 4 Effect of UO126 on RA apoptosis induction in CPEC. CPEC were treated with RA at $10^{-7} \mathrm{~mol} / \mathrm{l}$ with and without UO126 at $10^{-5} \mathrm{~mol} / \mathrm{l}$ for up $96 \mathrm{~h}$. Following treatment apoptosis was detected by the TUNEL method. Values represent the mean of three independent experiments performed in duplicate ( \pm S.E.) $P<0.05 ;{ }^{* \star} P<0.01$.

\section{Acknowledgements}

This work was supported in part by grants from MIUR 2002, Ateneo and IPSEN to A A S.

\section{References}

1 Gronberg H. Prostate cancer epidemiology. Lancet $2003 \mathbf{3 6 1}$ $859-864$

2 Kasamon KM \& Dawson NA. Update on hormone-refractory prostate cancer. Current Opinion in Urology 200414 185-193.

3 Evans TR \& Kaye SB. Retinoids: present role and future potential. British Journal of Cancer 199980 1-8.

4 Hammond LA, Brown G, Keedwell RG, Durham J \& Chandraratna RA. The prospects of retinoids in the treatment of prostate cancer. Anticancer Drugs 200213 781-790.

5 Gudas LJ, Sporn MB \& Roberts AB. Cellular biology and biochemistry of the retinoids. In The Retinoids: Biology, Chemistry, and Medicine, pp 597-630. Eds MB Sporn, AB Roberts \& DS Goodman. Orlando, FL: Academic Press, 1994.

6 Pollard M \& Luckert PH. The inhibitory effect of 4-hydroxyphenyl retinamide (4-HPR) on metastasis of prostate adenocarcinoma-III cells in Lobund-Wistar rats. Cancer Letters 199159 159-163.

7 Pienta KJ, Nguyen NM \& Lehe JE. Treatment of prostate cancer in the rat with synthetic retinoid fenretinide. Cancer Research 1993 $53224-226$.

8 Young Y-F, Murtha P, Andrews PE, Lindzey JK \& Tindall DJ. Antagonism of androgen action in prostate tumor cells by retinoic acid. The Prostate 199425 39-45.

9 Pasquali D, Thaller C \& Eichele G. Abnormal level of retinoic acid in prostate cancer tissues. Journal of Clinical Endocrinology and Metabolism 199681 2186-2191.

10 Pasquali D, Rossi V, Prezioso D, Gentile V, Colantuoni V, Lotti T, Bellastella A \& Sinisi AA. Changes in tissue transglutaminase activity and expression during retinoic acid-induced growth arrest and apoptosis in primary cultures of human epithelial prostate cells. Journal of Clinical Endocrinology and Metabolism $1999 \mathbf{8 4}$ 1463-1469.

11 Zhang XK. Vitamin A and apoptosis in prostate cancer. EndocrineRelated Cancer 20029 87-102.

12 Nagy L, Thomazy VA, Heyman RA \& Davies PJA. Retinoic acidinduced apoptosis in normal and neoplastic tissues. Cell Death and Differentiation 19985 11-19. 
13 Giguere V. Retinoic acid receptors and cellular retinoid binding proteins: complex interplay in retinoid signaling. Endocrine Reviews $19941561-79$.

14 Cho Y, Klein MG \& Talmage DA. Distinct functions of protein kinase $\mathrm{Ca}$ and protein kinase $\mathrm{Cb}$ during retinoic acid-induced differentiation of F9 cells. Cell Growth and Differentiation 19989 147-154.

15 Hoyos B, Imam A, Chua R, Swenson C, Tong GX, Levi E, Noy N \& Hammerling $\mathrm{U}$. The cysteine-rich regions of the regulatory domains of Raf and protein kinase $\mathrm{C}$ as retinoid receptors. Journal of Experimental Medicine 2000192 835-845.

16 Radominska-Pandya A, Chen G, Czernik PJ, Little JM, Samokyszyn VM, Carter CA \& Nowak G. Direct interaction of all-trans-retinoic acid with protein kinase $\mathrm{C}$ (PKC). Implications for PKC signaling and cancer therapy. Journal of Biological Chemistry $2000 \mathbf{2 7 5} 22324-22330$.

17 Imam A, Hoyos B, Swenson C, Levi E, Chua R, Viriya E \& Hammerling U. Retinoids as ligands and coactivators of protein kinase Ca. FASEB Journal 200115 28-30.

18 Cho Y \& Talmage DA. Protein kinase Ca expression confers retinoic acid sensitivity on MDA-MB-231 human breast cancer cells. Experimental Cell Research 2001269 97-108.

19 Nakagawa S, Fujii T, Yokoyama G, Kazanietz MG, Yamana H \& Shirouzu K. Cell growth inhibition by all-trans retinoic acid in SKBR-3 breast cancer cells: involvement of protein kinase C alpha and extracellular signal-regulated kinase mitogen-activated protein kinase. Molecular Carcinogenesis 200338 106-116.

20 Pedram A, Razandi M, Aitkenhead M, Hughes CC \& Levin ER. Integration of the non-genomic and genomic actions of estrogen. Membrane-initiated signaling by steroid to transcription and cell biology. Journal of Biological Chemistry 2002277 50768-50775.

21 Sinisi AA, Chieffi P, Pasquali D, Kisslinger A, Staibano S Bellastella A \& Tramontano D. EPN: a novel epithelial cell line derived from human prostate tissue. In Vitro Cellular and Developmental Biology. Animal 200238 165-172.

22 Spaulding SW. The ways in which hormones change cyclic adenosine $3^{\prime}, 5^{\prime}$-monophosphate-dependent protein kinase subunits, and how such changes affect cell behavior. Endocrine Reviews $199314632-650$.

23 Farini D, Puglianiello A, Mammi C, Siracusa G \& Moretti C. Dual effect of pituitary adenylate cyclase activating polypeptide on prostate tumor LNCaP cells: short- and long-term exposure affect proliferation and neuroendocrine differentiation. Endocrinology $20031441631-1643$.

24 Uzgare AR \& Isaacs JT. Enhanced redundancy in AKT and mitogen-activated protein kinase-induced survival of malignant vs normal prostate epithelial cells. Cancer Research $2004 \mathbf{6 4}$ $6190-6199$.
25 Martin-Blanco E. p38 MAPK signalling cascades: ancient roles and new functions. Bioessays $200022637-645$.

26 Nebreda AR \& Porras A. p38 MAP kinases: beyond the stress response. Trends in Biochemical Sciences 200025 257-260.

27 Pearson G, Robinson F, Beers Gibson T, Xu BE, Karandikar M, Berman K \& Cobb MH. Mitogen-activated protein (MAP) kinase pathways: regulation and physiological functions. Endocrine Reviews 200122 153-183.

28 Chang L \& Karin M. Mammalian MAP kinase signalling cascades. Nature $2001 \mathbf{4 1 0} 37-40$.

29 Giannì M, Kopf E, Bastien J, Oulad-Abdelghani M, Garattini E, Chambon P \& Rochette-Egly C. Down-regulation of the phosphatidylinositol 3-kinase/Akt pathway is involved in retinoic acidinduced phosphorylation, degradation, and transcriptional activity of retinoic acid receptor gamma. Journal of Biological Chemistry 2002277 24859-24862.

30 Jho EH, Davis RJ \& Malbon CC. c-Jun amino-terminal kinase is regulated by $\mathrm{Ga}_{12} / \mathrm{Ga}_{13}$ and obligate for differentiation of P19 embryonal carcinoma cells by retinoic acid. Journal of Biological Chemistry 1997272 24468-24474.

31 Yen A, Roberson MS \& Varvayanis S. Retinoic acid selectively activates the ERK2 but not JNK/SAPK or p38 MAP kinases when inducing myeloid differentiation. In Vitro Cellular and Developmental Biology. Animal 199935 527-532.

32 Yen A \& Varvayanis S. Retinoic acid increases amount of phosphorylated RAF; ectopic expression of cFMS reveals that retinoic acid-induced differentiation is more strongly dependent on ERK2 signaling than induced GO arrest is. In Vitro Cellular and Developmental Biology. Animal 200036 249-255.

33 Bost F, Caron L, Marchetti I, Dani C, Le Marchand-Brustel Y \& Binetruy B. Retinoic acid activation of the ERK pathway is required for embryonic stem cell commitment into the adipocyte lineage. Biochemical Journal $2002361621-627$

34 Marshall CJ. Specificity of receptor tyrosine kinase signaling: transient versus sustained extracellular signal-regulated kinase activation. Cell $1995 \mathbf{8 0} 179-185$.

35 Vanoverberghe K, Vanden Abeele F, Mariot P, Lepage G, Roudbaraki M, Bonnal JL, Mauroy B, Shuba Y, Skryma R \& Prevarskaya N. $\mathrm{Ca}^{2+}$ homeostasis and apoptotic resistance of neuroendocrine-differentiated prostate cancer cells. Cell Death and Differentiation $200411321-330$.

Received 11 November 2004

Accepted 15 December 2004 